\title{
UNESCO MIL CITIES NETWORK AS OPPORTUNITY FOR DEVELOPMENT IN AFRICA
}

\author{
Felipe Chibás Ortiz PhD.
}

Associate professor at University of São Paulo, Representative of the Regional Committee for Latin America and the Caribbean of UNESCO MIL Alliance, Co-leader UNESCO Gown and Town initiative, Sao Paulo, Brazil

\section{Veronica Yarnykh PhD}

Associate professor at Faculty of Journalism, Head of Department, Co-leader UNESCO Gown and Town initiative, UNESCO expert, Director of International Competence Center for media education (RMA), Moscow, Russian Federation

\section{Emmanuel Komi Kounakou, PhD}

Director of Research and Partnership of PAFEME, A. Researcher UNESCO Chair of Communication and Technologies for Development University of Quebec in Montreal, Québec,

\section{Canada}

\begin{abstract}
The main objective of this article is to show the opportunities that can open up for African cities from the UNESCO MIL Cities approach. The methodology used was the theoretical-practical based on the bibliographical review and the narrative of the authors' experiences. MIL Cities is a UNESCO framework that speaks of the need to build or reform urban spaces so that they use new technologies but using them ethically and respectfully for vulnerable groups, transcending cultural barriers to communication and contributing to the objectives of the 2030 agenda. The article has three parts. The first part insists on the definition of the MIL Cities concept, its origin and the preliminary work that has been done to support its implementation. An exhaustive explanation is given of the 13 Indicators and 252 metrics of MIL Cities published by Chibás Ortiz and other authors. The creation of the UNESCO World Network of MIL Cities is discussed. The second part explains the role of metrics in the evaluation of MIL projects in towns and cities. This second part focuses also on the practical implementation strategies and cases deployed to spread the concept and its objectives. A particular emphasis is placed on the various webinars organized and their format though the whole world. This part summarizes actions and events taken to promote the initiative. The third part focuses on the Latin America \& Africa MIL Cities initiative. In this last section, the article focuses on the launch of the project and on the objectives to be achieved to develop MIL Cities in Africa. It highlights the countries involved in the project launch activities, the promotional strategies to be deployed to disseminate the concept to all countries on the continent. It is concluded that the MIL Cities framework opens up new possibilities for the growth and development for African cities.
\end{abstract}

Key words: UNESCO; MIL cities; Media and Information Literacy; 2030 Agenda; Africa.

\section{INTRODUCTION}

Cities around the world have benefited greatly from the digital revolution. This became most apparent during the pandemic that broke out in 2020, after which many services, operations, businesses, banks, governments, and people working predominantly in the analog world quickly began to digitize (UNESCO, 2020). Many interested cities are promoting "smart city" initiatives. These initiatives seek the efficiency of the management processes of urban spaces, they often underestimate citizen intelligence and their participation in the process. On the other hand, this has greatly concerned organizations such as UNESCO (2021) and the World Health Organization (WHO, 2021) since health in cities is highly influenced by the management of new communication technologies, as well as the access that its citizens have to information, by physical and digital vehicles. The weight of negative phenomena such as the infodemic or information epidemic has also increased with the increase in fake news, overinformation, etc. The new trends in Media and Information Literacy (MIL) emphasized the importance of creative thinking and of innovation together with critical 


\section{Yinternational Research Journa}

p-ISSN 2202-2821 e-ISSN 1839-6518 (Australian ISSN Agency)

thinking to empower people in their citizen rights and emphasize the importance of assessment and assessments with specific metrics.

\section{II.MIL Cities Approach}

The MIL Cities approach, a new UNESCO concept (UNESCO, 2018) is not limited to the use of technology to make city processes more efficient in traditional sectors and actors in education. The MIL Cities concept shows a more multisectoral and multidisciplinary approach to this issue and involves what we call the 5 agents of open social innovation are present as active managers: government representatives, academia, startups and companies, artists, and citizens.

The MIL Cities concept is materialized through 13 Indicators and 252 metrics. These indicators published by Chibás Ortiz and Alton Grizzle in chapter Zero of the book FROM SMART CITIES TO MIL CITIES, Metrics inspired by UNESCO's vision (Chibás Ortiz, et. al. 2020).

The questions we will try to answer here is, if it is possible to extend UNESCO's MIL Cities network in African cities? What are the opportunities that the MIL Cities framework opens for cities in Africa and other parts of the world?

MIL Cities open up a range of opportunities for African cities and those from other latitudes. This concept places at its heart the overcoming of cultural barriers to communication (UNESCO, 2019) MIL theory and methodology teaches us to carefully analyze messages and reality in a more objective way, without prejudices or cultural barriers such as those related to ethnicity, race, religion, different cultural identities, gender, and migration (UNESCO, 2021-a).

But to build MIL cities it is necessary to first diagnose and then try to remove or overcome the Cultural Barriers to communication. We have discussed this at various seminars organized by UNESCO's Gown and Town initiative.

MIL cities include or have synergy with the proposals of the Educational Cities, Healthy Cities, Sustainable Cities, Innovative Cities, which are spaces to catalyze civic participation and empower citizen participation.

MIL Cities (Media Information Literacy Cities) are cities that use new technologies and available resources but based on the sustainable post-human development of all social strata that integrate it in an ethical, inclusive, participatory and citizen way, and not only based on the financial growth. and technological. In this way of understanding the city, communication is means and message, as Marshall McLuhan would say, this is communication is everything; both for what
Vol. 11 No. 022021 828011022021172 (c) Author(s)

happens in the digital city and what happens in the physical city (Chibás Ortiz et. al. 2020).

It should be noted that the MIL Cities framework can also be applied in smaller urban spaces, which can be neighborhoods, communities, towns, corporate cities, and university city campuses (Chibás Ortiz, F; Dias A. P. Fischer, R. 2020, Romano, 2020).

They are always cited as examples from MIL Cities, Stockholm, Bedford, São Luis, and Helsinki. They are European and North American cities. But can we build or reform MIL Cities outside these countries and on other continents?

Led by UNESCO's Alton Grizzle, Felipe Chibás and Veronica Yarnykh, we hosted the World Cities Day webinar. This webinar was attended by Senator Delroy Williams, Mayor of Kingston, Jamaica; Mr. Sergio Arturo de la Luz Vergara Berdejo, Secretary of Culture of the Government of Puebla, Mexico and Mr. Carlos Paredes, Director of Industries of the Central Department of Paraguay, representing Mr. Hugo González, Governor of the Central Department of Paraguay. These cities will initiate a pilot of MIL Cities in their urban spaces. In this webinar the World Network of MIL Cities was officially created ${ }^{1}$.

\section{MIL cities future strategies to implement the concept}

The development of the global media space goes in many ways in the modern information world. The UNESCO MIL City approach in this regard is one of the most promising and interesting ones. The development of the concept of a media literate city in the context of the COVID 19 infodemic, as well as the digital transformation of the media space, requires changes in approaches, methods, and technologies.

In this regard, the experience of the UNESCO MIL City initiative has received an additional boost to development over the past year. Considering the requirements of the digital transformation of the communication and information environment, it was necessary to find new technologies for interacting with the audience and tools for developing the initiative in fundamentally new conditions.

1 UNESCO (2020), World Cities Day. In : MIL Clicks https://www.facebook.com/MILCLICKS/videos/81345474278 $\underline{8740}$

11 


\section{Yinternational Resoarch Journa}

p-ISSN 2202-2821 e-ISSN 1839-6518 (Australian ISSN Agency)

The practical experience of developing the UNESCO MIL City initiative, first of all, showed the effectiveness of organizing webinars as one of the ways to form a common information space for the initiative. Today, in the context of digital transformation, it is not enough to simply host a few webinars to promote an initiative. In the conditions of the existing information noise, a huge volume of fakes and misinformation, clip thinking, any events should have powerful communication and information support. In such conditions of information pressure on the audience, it would be strategically correct to implement the following actions to form and promote the UNESCO MIL City initiative.

First of all, webinars by themselves no longer have such value. But it is the webinar as an information entry point that carries the main value for the audience. The webinar today is the center for the formation of information and communication space and the main information value. Experts from different fields take part in the webinar in the MIL Talk format. This creates a second core value for the initiative. MIL City is an integrated and multidisciplinary approach to the development of the urban environment, mainly information and media. Experts from different environments look at the problem differently, which means they have the opportunity to show different opportunities for finding development opportunities. For example, under discussing the strategic development of media education in MIL City, experts from Pontifical University of Holy Cross (Rome), Association of media education of Italy, professor from Canada, Vice-President of Business Women World Association took part. It's a big advantage of our approach to gather people from different countries, continents, fields.

Another important factor was the format of the webinar itself. We have come up with a new discussion format called MIL Talk. This is a format of free discussion between experts, an opportunity not just to express thoughts, ideas, opinions. It is also an opportunity for every expert to have a fairly large presentation on the topic, an opportunity to demonstrate his position. Thus, the combination of the discussion and a large speech on the topic, the opportunity to exchange views and ideas, as well as a sufficiently large and professional role of the presenter, makes it possible to maximize the declared topic (Yarnykh, 2021-a).

The second important factor in the strategic development of the initiative was the chosen new information focus. The idea of sustainable development has become such a focus. The Sustainable Development Goals (SDG) today are an opportunity for a new effective development of urban media space. It is this kind of development of the urban media space,
Vol. 11 No. 022021 828011022021172 (C) Author(s)

the use of new mechanisms that makes it possible to create a comfortable living environment, including in the media space. An interdisciplinary approach and a comprehensive assessment of the media city through sustainable development provide an opportunity for a fundamentally new and comprehensive development of the media space. And sustainable development metrics (ESG) allow us to take a fresh look at the MIL City assessment process.

All this together allows us to find new opportunities not only for the development of African cities. First of all, we now live in two realities that form a comfortable and comfortable urban environment (Yarnykh, 2021). And the development of media reality can be very effectively supported through the MIL City approach. Additional opportunities for the effect of sustainable development give us a new focus for this.

\section{MIL Cities concept in the specific conditions of African cities}

The major digital transformations of the past ten years in Africa have radically shaped our relationship with media use (Kounakou, Agbobli, 2018) and our living environments in towns and villages. But this media and digital use without ethical regulation expose many people to various risks. How could UNESCO MILCities Initiative be a solution to this divide in African societies? Before talking about it, let's briefly overview first smart cities projects developed on the continent between 2007 and 2010.

First, The African Digital Cities (ADC) ${ }^{2}$ project was initiated to promote African digital towns and villages, communities, and sustainable mastering of digital tools. Then, in 2014, the African Union project "Agenda 2063: The Africa We Want" outlines the blueprint for Africa's digital transformation into a powerful global digital platform of the future. In 2019, a partnership between PAFEME and Professor Felipe Chibás Ortiz resulted in the deployment of UNESCO MILCities Initiative in Canada and Africa. Two international webinars were held.

\section{The Latin America and African MILCities Initiative launch webinar}

This first exploratory meeting focused on the topic: "Mil Cities around the World: Education in Quebec, Brazil and in Africa" (2020). It showed the necessity of building MILCities Project in Africa. Following this first webinar, an article

\footnotetext{
${ }^{2}$ Kounakou (2008). From Digital City Label to the Africa Digital Cities project: proposal for a manual for adapting the label to African communities. University of Toulouse.
} 
entitled « Role of associations, unions, NGOs, socio-cultural projects in the construction of MIL Cities: a comparison between Canada and Africa» (Kounakou, Chibás Ortiz, 2021) was published to better understand the Canadian and African digital context before thinking about the operationalization of the UNESCO MILCities project in both continents.

\section{Latin America \& Africa Milcities Initiaitve}

The second webinar « indicators and metrics of MILCities their application in Africa (May 24 $4^{\text {th }}, 21$ ) » was organized to launch the Project in Africa. Experts from 8 countries (Benin, Burkina Faso, France, Ivory Coast, Kenya, Mali, Togo, and Tunisia) took part in this launch meeting. Through various communications, speakers insisted on the need for citizens, NGOs, institutions, schools, and other social actors to develop community media literacy to reduce digital divide and strengthen the ethical and inclusive use of technologies in our daily practices. Clearly, the MILCities project for Africa is an essential catalyst for transforming digital practices and bringing each citizen to enter the new digital age with confidence. But, how?

\section{Ways and strategies to mobilize to deploy MIL Cities in Africa}

To ensure the success of this project in Africa, we need:

a. to create a continental office and country representations to manage the project,

b. organize annual African MILCities Awards (AAMCA) to evaluate the project,

c. associate university institutions as poles of MILCities spreading in each country,

d. partner with NGOs to spread the project everywhere in Africa,

e. work with interstate institutional partners from and above Africa on common strategies.

The Latin America and Africa MILCities is a great project to develop African communities, and it is up to us to work hard to deploy it as quickly as possible. The Africa office is under construction and needs you to be operational.

\section{Final Words}

Is it possible to extend UNESCO's MIL Cities network in African cities and joining this network opens a new set of opportunities for African cities and other parts of the world? These opportunities could be realized in a faster and stronger way, if we work together with all stakeholders (governments, scientists, universities, educators, companies, startups, press, NGOs, artists, and citizens) on MIL innovative policies, strategies, and projects in networks together in different countries, cities, and continents, exchanging experiences and mutual contributions.

\section{References}

[1]. Chibás Ortiz, F.; Grizzle, A.; Borges, A.; Ramos, F.; Mazzetti, B.; Silva Junior, O., MIL Cities Metrics (2020), Cultural Barriers and Artificial Intelligence analyzed from the perspective of UNESCO: São Paulo case. In: Yanaze, M., Chibás Ortiz, F. (Ed.) From Smart Cities to MIL Cities, Metrics inspired by UNESCO`s vision, University of São Paulo, São Paulo.

[2]. Chibás Ortiz, F; Dias A. P. Fischer, R. (2020) MIL (Media and Information Literacy) University Cities: new metrics for education and urban health, In: MICMedia, Information Communication, Number 33, 15.08.2020, ISSN: 231-755X, Available: http://mic.org.ru/vyp/33-nomer-2020/felipe-chib-sortiz-ana-paula-d-as-rachel-fischer-mil-media-andinformation-literacy-university-citi

[3]. Felice, M.D. (2012) Digital halo: the crisis of central points of view and the end of the exclusive right to edit information. In: OLIVEIRA, Ivone de Lourdes; MARCHIORI, Marlene (Org.) Social networks, communication and organizations, São Paulo: Diffusion.

[4]. Kounanou, E. K., Christian Agbobli (2018), «Regards croisés sur les stratégies d'éducation aux médias en Afrique de l'Ouest : les cas du Togo et du Bénin», pp.183-208, Revue Éducation comparée nouvelle série, «Les politiques d'éducation à l'information, aux médias et au numérique dans le monde», sous la direction de Anne Lehmans, Vincent Liquète et Louise Limberg, vol. 19.

[5]. Kounakou, E. K.., Chibás Ortiz, F. (2021) Role of associations, unions, NGOs, sociocultural projects in the construction of MIL Cities: a comparison between Canada and Africa, In: La red de ciudades MIL de UNESCO y Agenda 2030: educación, comunicación y salud sostenible, La Habana: Pueblo y Educación, 2021 (no prelo).

[6]. Romano, R. (2020) University Cities as MIL Cities: Case Study of FACENS University Center, In: Yanaze, M., Chibás Ortiz, F. (Ed.) From Smart Cities to MIL Cities, Metrics inspired by UNESCO`s vision, University of São Paulo, São Paulo. 
[7]. Yarnykh V. (2021) Media Technologies in the Corporate Model of Media Education: Opportunities and Prospects. DESIDOC Journal of Library \& Information Technology, Vol. 41, No. 4, July 2021, pp. 1-6, DOI: 10.14429/djlit.41.4.17140

[8]. Yarnykh V. (2021-a) Media Education in Corporate Education's Ecosystem. International Journal of Latest Research in Humanities and Social Science (IJLRHSS), Vol. 4, issue 3, 2021 - p. 9-15

[9]. UNESCO (2018) Media and Information Literate Cities, https://en.unesco.org/milcities

[10]. UNESCO (2019) Belgrade Recommendations on Draft Global Standards for Media and Information Literacy Curricula Guidelines, https://en.unesco.org/sites/default/files/belgrade_reco mmendations_on_draft_global_standards_for_mil_cu rricula_guidelines_12_november.pdf

[11]. UNESCO, (2020), Seoul Declaration on Media and Information Literacy for Everyone and by Everyone,
Accessible en: https://en.unesco.org/news/seouldeclaration-media-and-information-literacyeveryone-and- everyone- 0

[12]. UNESCO (2021), Windhoek + 30 Declaration, Accessible en:https://en.unesco.org/sites/default/files/windhoek3 Odeclaration_wpfd_2021.pdf

[13]. UNESCO (2021-a), MIL Curriculum Summary: "Media and Information Literate Citizens: Think Critically, Click Wisely!" https://en.unesco.org/news/media-and-informationliterate-citizens-think-critically-click-wisely Access: 24/04/2021

[14]. WHO (2021) Public Health Research Agenda for Managing Infodemics. Geneva: World Health Organization. Available at: https://www.who.int/publications/i/item/9789240019 508 Accessed on: 07/16/2020 


\section{Manuscript Processing Footprints}

\section{A. Journal Volume/Issue Details}

This manuscript it published in Vol. 11 No. 022021 issue of IARS' International Research Journal (I'IRJ).

This is a Peer Reviewed (Refereed) International Journal published by IARS' Press Australia (International Association of Research Scholars) The Volume/Issue is a regular issue of the journal published in August 2021 Available at: https://researth.iars.info/index.php/curie.

\section{B. Copyright, License, and Publishing Rights}

- IARS' Press Australia (International Association of Research Scholars) respects the rights of the authors of research content published with IARS' International Research Journal. The "First Publication Rights" (FPR) to the original work accepted for publication at IARS' International Research Journal is granted to the Publisher of the Journal but copyright for all work published in the journal is retained by the author(s). Works published in the Journal is distributed under a Creative Commons Attribution 4.0 International License (CC B Y 4.0). (This license lets others distribute, remix, adapt, and build upon your work, even commercially, as long as they credit you for the original creation. This is the most accommodating of licenses offered. Recommended for maximum dissemination and use of licensed materials.)

- After publishing the content with IARS' International Research Journal, the author holds complete right on the content for its amendments and reuse in any form. IARS' International Research Journal confirms that author(s) holds the copyright of the content.

- $\quad$ Author(s) grant(s) permission for their work to be indexed in part/full form in commercial and non-commercial indexes. Author(s) grant(s) permission for their work to be harvested in part/full form in commercial and non-commercial archives and distributed through them. Author(s) grant(s) permission for their work to be translated in part/full form in any language and republished and redistributed. Author(s) may enter into separate, additional contractual agreements for the non-exclusive distribution of the published version of the work, with an acknowledgement of its initial publication in this Journal.

- It is the responsibility of the author(s) to secure all necessary copyright and/or permissions for the use of third-party content in their manuscript(s). Author(s) have declared the same at the time of submission of manuscript and 'may also be required' to provide written evidence of this permission anytime in case required for any purposes.

- Publications Ethics and other Terms and Conditions as mentioned on official website of IARS' International Research Journal.

\section{Last Plagiarism Report}

Settings: Similarity of 09 words in a row has been considered plagiarized.

Plagiarized (2\%)

Unique (98\%)

\begin{tabular}{|l|l|}
\hline Date & Aug 13, 2021. \\
\hline Words & 50 Words Plagiarized / Total Words 2957. \\
\hline Source & 3 Source(s) Identified. \\
\hline Remarks & Low similarity detected, check your supervisor if changes are required. \\
\hline
\end{tabular}

Exemption / Relaxation by Editor: None

\section{Processing Track}

\begin{tabular}{|l|l|}
\hline Date of Submission & 1 August 2021 \\
\hline Date of Final Review & 12 August 2021 \\
\hline Date of Acceptance \& Schedule & 15 August 2021 \\
\hline Date of Publishing & 29 August 2021 \\
\hline
\end{tabular}

